\title{
Relative Effects of Fertilizer Nitrogen Form and Phosphate Level on Control of Bedding Plant Seedling Growth
}

\author{
Paul V. Nelson ${ }^{1}$ \\ Department of Horticultural Science, North Carolina State University, Box \\ 7609, Raleigh, NC 27695-7609
}

Cheon-Young Song

Korea National College of Agriculture and Fisheries, 11 Dongwhari

Bongdam Hwasunsi Kyonggido, R.O. Korea 445-890

\section{Jinsheng Huang \\ Department of Environmental Horticulture, University of Florida, Gainesville, FL 32611}

Carl E. Niedziela, Jr.

School of Natural Sciences and Mathematics, Ferrum College, PO Box 1000, Ferrum, VA 24088

William H. Swallow

Department of Statistics, North Carolina State University, Raleigh, NC 27695-8203

Additional index words. Gomphrena globosa, Impatiens wallerana, Solanum esculentum, Petunia $\times$ hybrida, Tagetes erecta, nitrate-to-ammonium ratio, low phosphorous stress

\begin{abstract}
Fertilizers with a high proportion of nitrogen $(\mathrm{N})$ in the nitrate $\left(\mathrm{NO}_{3}^{-}\right)$form are used in the ornamental industry to promote compactness in plants. Although the common belief is that it is the high proportion of $\mathrm{NO}_{3}{ }^{-}$that causes compactness, these formulations also contain no or a low level of phosphate, which can also cause compactness. This study was conducted to assess the relative effects of $\mathrm{NO}_{3}{ }^{-}$to ammonium $\left(\mathrm{NH}_{4}{ }^{+}\right)$ratio and phosphate supply, as found in high $\mathrm{NO}_{3}{ }^{-}$fertilizers, on seedling shoot growth. A series of fertilizers was formulated in which the level of phosphate and proportion of $\mathrm{N}$ in the $\mathrm{NO}_{3}$ form were varied factorially. Additionally, commercial fertilizers varying in these same two nutrient components were tested to verify the results obtained using the formulated fertilizers. Test plants included gomphrena (Gomphrena globosa L.), impatiens (Impatiens wallerana Hook. F.), petunia (Petunia $\times$ hybrida Juss.), marigold (Tagetes erecta $\mathbf{L}$.), and tomato (Solanum esculentum Mill.) grown as plug seedling crops. A strong inverse relationship occurred between the supply of phosphate and extent of compactness. The relationship between proportion of $\mathrm{N}$ in the $\mathrm{NO}_{3}{ }^{-}$form and compactness was comparatively small. In most comparisons within the study, shoot size increased with increasing proportion of $\mathrm{NO}_{3}{ }^{-}$, contrary to common belief. These data indicate that it is the limited phosphate level in high $\mathrm{NO}_{3}{ }^{-}$fertilizers that accounts for compactness rather than the high proportion of $\mathrm{N}$ in the $\mathrm{NO}_{3}{ }^{-}$form.
\end{abstract}

Many ornamental greenhouse crops are grown under some form of stress or growth regulation that limits the full potential for their shoot volume production. This is universally true for young plants produced in plug seedling

Received for publication 14 Oct. 2011. Accepted for publication 13 Nov. 2011.

This research was funded in part by a grant from Bedding Plants Foundation, Inc., Lansing, MI, and by the North Carolina Agricultural Research Service (NCARS), Raleigh, NC.

Use of trade names does not imply endorsement by the NCARS of products named nor criticism of similar ones not mentioned.

${ }^{1}$ To whom reprint requests should be addressed; e-mail paul_nelson@ncsu.edu. trays and bedding plant flats where limited horizontal space tends to increase vertical growth. Commercial methods of shoot control have included restricted watering (Schnelle et al., 1993), low fertility, which mainly translates into N stress (Styer and Koranski, 1997), temperature manipulation (Berghage and Heins, 1991), and chemical growth retardants (Gaston et al., 2001; Tayama et al., 1992). The respective problems associated with these procedures in the order just presented are desiccation of tissue and possible leaf abscission, chlorotic foliage, and high cost of growth regulators and their very limited registration for use on vegetable seedlings.

In addition to the four forms of shoot control, greenhouse production managers often use the form of $\mathrm{N}$ to control shoot size (Styer and Koranski, 1997). The belief is that fertilizers with high proportions of $\mathrm{NO}_{3}{ }^{-}$produce compact shoots (smaller leaves and shorter internodes), whereas those with high proportions of $\mathrm{NH}_{4}^{+}$yield large shoots. This is achieved by using high $\mathrm{NO}_{3}{ }^{-}$fertilizers such as $15 \mathrm{~N}-$ $0 \mathrm{P}-12.5 \mathrm{~K}, 14 \mathrm{~N}-0 \mathrm{P}-11.6 \mathrm{~K}$, and $17 \mathrm{~N}-0 \mathrm{P}-$ $14.1 \mathrm{~K}$ formulated from combinations of calcium nitrate $\left[\mathrm{Ca}\left(\mathrm{NO}_{3}\right)_{2}\right]$, potassium nitrate $\left(\mathrm{KNO}_{3}\right)$, and magnesium nitrate $\left[\mathrm{Mg}\left(\mathrm{NO}_{3}\right)_{2}\right]$. Our experience with forms of $\mathrm{N}$ has not shown a relationship with shoot size. Because high $\mathrm{NO}_{3}{ }^{-}$fertilizers typically contain little or no phosphate, we hypothesized that it is a low phosphorus (P) stress brought on by using these fertilizers that accounts for suppression of shoot growth rather than their high proportion of $\mathrm{NO}_{3}^{-}$.

Plant species vary greatly in their response to $\mathrm{NO}_{3}{ }^{-}$and $\mathrm{NH}_{4}{ }^{+}$(Haynes and Goh, 1978). There are reports of $100 \% \mathrm{NO}_{3}{ }^{-}$limiting plant growth in some species, including Ageratum houstonianum Mill. (Jeong and Lee, 1992), carnation (Dianthus caryophyllus L.) (Green et al., 1973), and wheat (Triticum aestivum L.) (Cox and Reisenauer, 1973). In contrast, most species grow better with mixtures of $\mathrm{NH}_{4}{ }^{+}$ and $\mathrm{NO}_{3}{ }^{-}$, with up to $50 \%$ of $\mathrm{N}$ in the $\mathrm{NH}_{4}{ }^{+}$ form (Gaffney et al., 1982; Jeong and Lee, 1992; Schrock and Goldsberry, 1982). Minimal effect of the $\mathrm{NO}_{3}{ }^{-}$to $\mathrm{NH}_{4}{ }^{+}$ratio on plant shoot growth had been observed on Impatiens wallerana Hook F. (Argo and Biernbaum, 1997) and Lobelia erinus L. 'Cobalt' (Jeong and Lee, 1992). These variable results could be the result of an unchecked impact of the fertilizer $\mathrm{NH}_{4}{ }^{+}: \mathrm{NO}_{3}{ }^{-}$ratio on root substrate $\mathrm{pH}$ and subsequent effects on nutrient availability.

Bedding plant growth can also be controlled by limiting the supply of phosphate in root media (Gibson et al., 2007; Huang and Nelson, 1994). Plants receiving a low level of phosphate resulted in compact shoots. It was found that growth inhibition by $\mathrm{P}$ deficiency is selective, affecting shoots much more than roots for many species, resulting in an often-desirable higher root-to-shoot ratio (Goldstein et al., 1988; Huang and Nelson, 1994; Loneragan and Asher, 1967; Trull et al., 1997).

The objective of this study was to assess the relative effects of $\mathrm{NO}_{3}{ }^{-}$to $\mathrm{NH}_{4}{ }^{+}$ratio and phosphate supply, as found in high $\mathrm{NO}_{3}{ }^{-}$fertilizers, on vegetable and bedding plant seedling shoot growth.

\section{Materials and Methods}

Treatments and cultural practices. Two experiments were conducted in glass greenhouses in Raleigh, $\mathrm{NC}$, at $35^{\circ}$ north latitude. The 15 fertilizer treatments established in the first experiment can be separated into four groups (Table 1). The phosphate series at low $\mathrm{NO}_{3}{ }^{-}$ (Treatments 1, 2, 3, and 4) all contained $60 \%$ of total $\mathrm{N}$ as $\mathrm{NO}_{3}{ }^{-}$but varied in phosphate-P levels where the equivalent elemental $\mathrm{P}$ levels were $0 \%, 3.3 \%, 6.6 \%$, and $21.8 \%$ of $\mathrm{N}$, respectively. The phosphate series at high $\mathrm{NO}_{3}{ }^{-}$ (Treatments 5, 6, 7, and 8) contained $100 \%$ of total $\mathrm{N}_{\text {as }} \mathrm{NO}_{3}{ }^{-}$with the same phosphate-P levels as Treatments 1,2,3, and 4, respectively. 


\begin{tabular}{|c|c|c|c|c|c|c|c|c|c|c|c|}
\hline \multirow[b]{3}{*}{ Treatment no. } & \multirow[b]{3}{*}{ Expt. } & \multirow[b]{3}{*}{$\mathrm{N}-\mathrm{P}-\mathrm{K}$} & \multirow[b]{3}{*}{$\mathrm{NO}_{3}^{-}(\% \mathrm{~N})^{\mathrm{y}}$} & \multirow[b]{3}{*}{$P(\% N)$} & \multicolumn{7}{|c|}{ Ionic concentrations in fertilizer solutions } \\
\hline & & & & & $\mathrm{NH}_{4}^{+}$ & $\mathrm{NO}_{3}^{-}$ & $\mathrm{H}_{2} \mathrm{PO}_{4}^{-}$ & $\mathrm{K}^{+}$ & $\mathrm{Ca}^{2+}$ & $\mathrm{SO}_{4}{ }^{2-}$ & $\mathrm{Mg}^{2+}$ \\
\hline & & & & & \multicolumn{7}{|c|}{$(\mathrm{mm})$} \\
\hline \multicolumn{12}{|c|}{ Phosphate series at low $\mathrm{NO}_{3}^{-}$} \\
\hline 2 & 1,2 & $20-0.7-16.6$ & 60 & 3.3 & 2.8 & 4.3 & 0.11 & 2.1 & 0.055 & 0.35 & 0 \\
\hline 3 & 1,2 & $20-1.3-16.6$ & 60 & 6.6 & 2.8 & 4.3 & 0.21 & 2.1 & 0.11 & 0.35 & 0 \\
\hline 4 & 1,2 & $20-4.4-16.6$ & 60 & 21.8 & 2.8 & 4.3 & 0.70 & 2.1 & 0.35 & 0.35 & 0 \\
\hline 6 & 1 & $15-0.5-12.5$ & 100 & 3.3 & 0 & 7.1 & 0.11 & 2.1 & 2.6 & 0 & 0 \\
\hline 7 & 1 & $15-1-12.5$ & 100 & 6.6 & 0 & 7.1 & 0.21 & 2.1 & 2.6 & 0 & 0 \\
\hline 8 & 1,2 & $15-3.3-12.5$ & 100 & 21.8 & 0 & 7.1 & 0.70 & 2.1 & 2.9 & 0 & 0 \\
\hline \multicolumn{12}{|c|}{$\mathrm{NO}_{3}^{-}$series at high phosphate } \\
\hline 4 & 1,2 & $20-4.4-16.6$ & 60 & 21.8 & 2.8 & 4.3 & 0.70 & 2.1 & 0.35 & 0.35 & 0 \\
\hline 9 & 1,2 & $20-4.4-16.6$ & 87 & 21.8 & 0.9 & 6.2 & 0.70 & 2.1 & 1.9 & 0 & 0 \\
\hline 11 & 1 & $17-0-14.1$ & 80 & 0 & 1.4 & 5.7 & 0 & 2.1 & 0.59 & 0 & 0.48 \\
\hline 12 & 1,2 & $15-0-12.5$ & 87 & 0 & 0.9 & 6.2 & 0 & 2.1 & 1.8 & 0 & 0 \\
\hline 13 & 1 & $14-0-11.6$ & 92 & 0 & 0.6 & 6.5 & 0 & 2.1 & 1.1 & 0 & 0.88 \\
\hline 14 & 1 & $13-0.9-10.8$ & 95 & 6.9 & 0.4 & 6.7 & 0.22 & 2.1 & 1.2 & 0 & 0.95 \\
\hline 15 & 1,2 & $15-3.3-12.5^{\mathrm{x}}$ & 87 & 21.8 & 0.9 & 6.2 & 0.70 & 2.1 & 2.2 & 0 & 0 \\
\hline
\end{tabular}

${ }^{\mathrm{z}}$ All treatments were applied at $100 \mathrm{mg} \cdot \mathrm{L}^{-1} \mathrm{~N}$ and $83 \mathrm{mg} \cdot \mathrm{L}^{-1} \mathrm{~K}$.

${ }^{y}$ Nitrate and $\mathrm{P}$ levels in the fertilizer solutions were expressed as a percentage of the total $\mathrm{N}$ in the solution.

${ }^{x}$ The 15-3.3-12.5 treatment was the 15-0-12.5 commercial fertilizer amended with $\mathrm{Ca}\left(\mathrm{H}_{2} \mathrm{PO}_{4}\right)_{2}$ to provide phosphate while maintaining the $\mathrm{N}$ to $\mathrm{K}$ ratio. $\mathrm{N}=$ nitrogen; $\mathrm{P}=$ phosphorus; $\mathrm{K}=$ potassium.

The $\mathrm{NO}_{3}{ }^{-}$series at high phosphate (Treatments $4,9,10$, and 8) contained the highest phosphate-P levels $(21.8 \%$ of $\mathrm{N})$ but varied in $\mathrm{NO}_{3}{ }^{-}$levels $(60 \%, 87 \%, 93 \%$, and $100 \%$ of total $\mathrm{N}$, respectively). We self-formulated the non-commercial fertilizers to avoid unknown proprietary contents and $\mathrm{NH}_{4}^{+}$that are present in some calcium nitrate sources.

The commercial fertilizer series (Treatments 11 to 15 ) included five high $\mathrm{NO}_{3}{ }^{-}$ fertilizers $\left(80 \%\right.$ to $92 \%$ of $\mathrm{N}$ as $\left.\mathrm{NO}_{3}^{-}\right)$from Masterblend International (Elwood, IL). Treatments 11 to 13 contained no phosphate, and Treatments 14 and 15 contained phosphate$P$ levels of $6.9 \%$ and $21.8 \%$ of $\mathrm{N}$, respectively.

Potassium was $83 \%$ of $\mathrm{N}$ level in all 15 treatments. Test plants included gomphrena (Gomphrena globosa 'Gnome Purple') and tomato (Solanum esculentum 'Better Boy').

A second experiment was conducted to assess reproducibility of the first for gomphrena and to extend the test plant crops to impatiens (Impatiens wallerana 'Super Elfin White'), petunia (Petunia $\times$ hybrida 'Madness White'), and marigold (Tagetes erecta 'Antigua Yellow'). Nine treatments were incorporated from the phosphate series at low $\mathrm{NO}_{3}^{-}$(Treatments 1 to 4$), \mathrm{NO}_{3}{ }^{-}$series at high phosphate (Treatments 4,8 , and 9), and commercial fertilizer series as described for the first experiment (Table 1). The commercial fertilizer group only included Treatments 12 and 15 .

In both experiments, seed were sown in 288-cell plug trays in a 3 sphagnum peatmoss: 1 perlite substrate $(\mathrm{v} / \mathrm{v})$ amended with dolomitic limestone and Micromax micronutrient mix (The Scotts Company, Marysville, $\mathrm{OH})$ at 3 and $0.45 \mathrm{~g} \cdot \mathrm{L}^{-1}$, respectively. Seeds were sown on 10 Oct. and 14 Dec. for Expts.
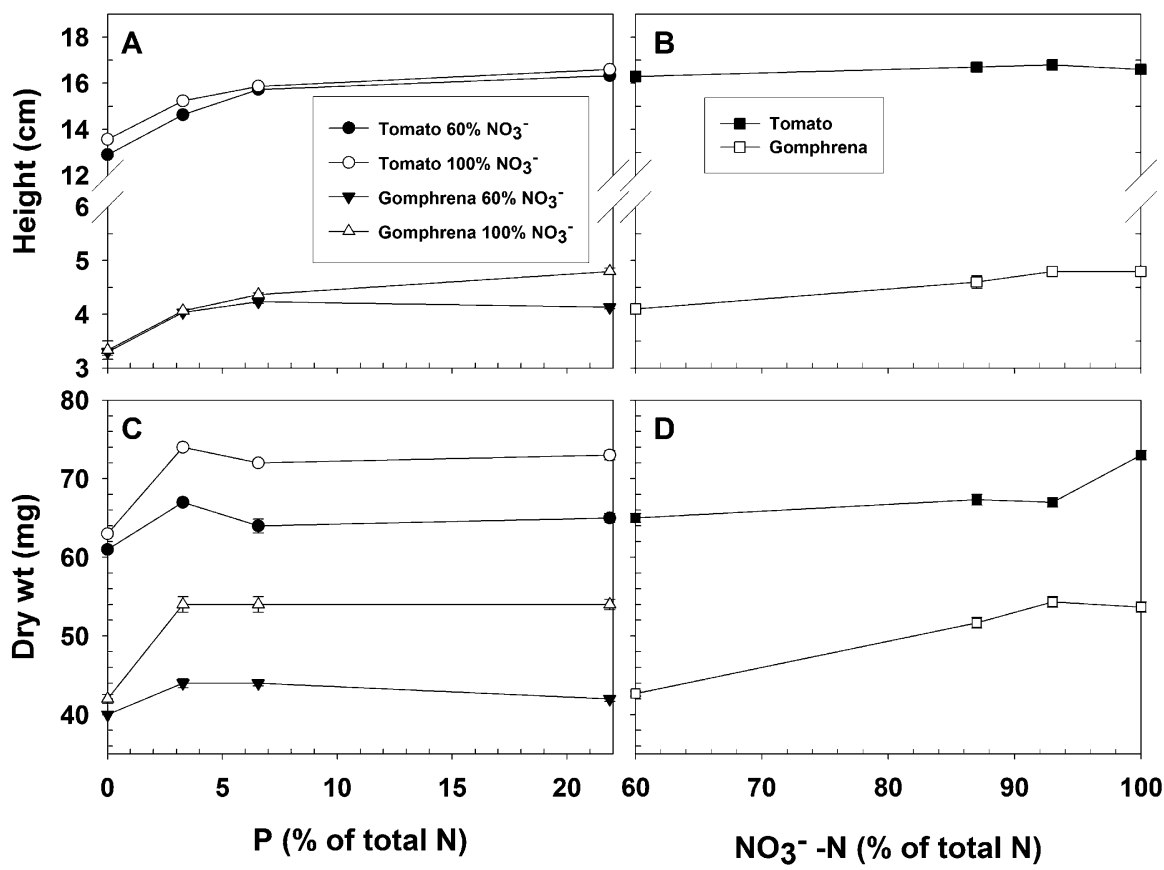

Fig. 1. Effect of fertilizer (A) phosphorus (P) levels expressed as a percentage of total $\mathrm{N}$ at two $\mathrm{NO}_{3}{ }^{-}$ proportions of total nitrogen $(\mathrm{N})$ and $(\mathbf{B}) \mathrm{NO}_{4}^{-}$proportions of total $\mathrm{N}$ on the height; also $(\mathbf{C}) \mathrm{P}$ levels expressed as a percentage of total $\mathrm{N}$ at two $\mathrm{NO}_{3}{ }^{-}$proportions of total $\mathrm{N}$ and (D) $\mathrm{NO}_{4}{ }^{-}$proportions of total $\mathrm{N}$ on the dry weight of seedling shoots of tomato and gomphrena at the end of plug stage 3 in Expt. 1. Vertical bars represent SE $(n=3)$.

1 and 2, respectively. After seeds were sown, trays were placed in a dark germination chamber at constant $24^{\circ} \mathrm{C}$. When radicles emerged and hooked downward (end of Stage 1), plug trays were removed from the chamber and placed on a greenhouse bench. For a 10-d period beginning at cotyledon separation, seedlings were fertilized with $20 \mathrm{~N}-4.4 \mathrm{P}-16.6 \mathrm{~K}$ commercial fertilizer at $50 \mathrm{mg} \cdot \mathrm{L}^{-1} \mathrm{~N}$. At that point, nutrient treatments were initiated and continued until the normal end of plug seedling production, 34 and $37 \mathrm{~d}$ in Expts. 1 and 2, 
respectively. All fertilizer treatments were applied at $100 \mathrm{mg} \cdot \mathrm{L}^{-1} \mathrm{~N}$.

Data collection. At the end of each experiment, substrates were sampled $1 \mathrm{~h}$ after fertilization. Substrate samples were squeezed by hand through one layer of cheesecloth. Extracted substrate solutions were analyzed for $\mathrm{pH}$, electrical conductivity (EC), $\mathrm{NO}_{3}{ }^{-}, \mathrm{NH}_{4}{ }^{+}$, phosphate- $\mathrm{P}, \mathrm{Ca}^{2+}, \mathrm{Mg}^{2+}$, and $\mathrm{K}^{+}$. $\mathrm{EC}$ and $\mathrm{pH}$ were measured using a Model $695 \mathrm{pH} /$ conductivity/TDS/temperature meter (Extech Instruments, Waltham, MA). Colorimetric analysis was performed for $\mathrm{NO}_{3}{ }^{-}$(Cataldo et al., 1975), $\mathrm{NH}_{4}^{+}$(Chaney and Marbach, 1962) and phosphate-P (concentrations under $10 \mu \mathrm{g} \cdot \mathrm{mL}^{-1}$; Murphy and Riley, 1962; and concentrations above $10 \mu \mathrm{g} \cdot \mathrm{mL}^{-1}$; Chapman and Pratt, 1961) on a Model Lambda 3 ultraviolet/VIS spectrophotometer (Perkin and Elmer, Norwalk, $\mathrm{CT})$. Potassium $(\mathrm{K})$, calcium $(\mathrm{Ca})$, and magnesium $(\mathrm{Mg})$ analysis was performed using an atomic absorption spectrometer Analyst 100 (Perkin-Elmer, Norwalk, CT).

Plants were harvested at the end of each experiment for shoot height and dry mass measurements. Fifty shoots from each plot were washed in $0.2 \mathrm{~N} \mathrm{HCl}$ for $30 \mathrm{~s}$, rinsed in deionized water, dried at $70{ }^{\circ} \mathrm{C}$, weighed, and ground to 1-mm particle size in a stainless steel Wiley Laboratory Mill Model 4 (Thomas Scientific, Philadelphia, PA) for tissue analysis. Total $\mathrm{N}$ was analyzed using a Kjeldahl procedure (Fleck and Davidson, 1974). Ground tissue was dry-ashed at $500{ }^{\circ} \mathrm{C}$, dehydrated in $\mathrm{HCl}$, and dissolved in $0.5 \mathrm{~N} \mathrm{HCl}$. Tissue $\mathrm{P}, \mathrm{K}, \mathrm{Ca}$, and $\mathrm{Mg}$ were measured by the same procedures used for substrate solution analyses.

Experimental design and statistical analysis. In Expt. 1, the phosphate series at both low and high $\mathrm{NO}_{3}{ }^{-}$(Treatments 1 to 8 ) were analyzed together as a two-factor factorial with two $\mathrm{NO}_{3}{ }^{-}$levels and four phosphate levels arranged in three blocks for a total of eight treatment combinations (24 experimental units). The $\mathrm{NO}_{3}{ }^{-}$series at high phosphate (Treatments 4, 8,9, and 10) were analyzed separately with four treatments arranged in three blocks (12 experimental units). The commercial series (Treatments 11 to 15 ) with the addition of Treatment 4 were also analyzed separately with six treatments arranged in three blocks (18 experimental units).

In Expt. 2, the phosphate series at the low $\mathrm{NO}_{3}^{-}$level (Treatments 1 to 4) were analyzed separately with four treatments arranged in three blocks (12 experimental units). The $\mathrm{NO}_{3}{ }^{-}$ series at high phosphate (Treatments 4, 8, 9, and 10) were analyzed separately with four treatments arranged in three blocks (12 experimental units). The commercial series (Treatments 10 and 13) with the addition of Treatment 4 were also analyzed separately with three treatments arranged in three blocks (nine experimental units).

Data were analyzed using SAS 9.1 (SAS Inst., Cary, NC) with analysis of variance (ANOVA) by PROC ANOVA and means separation by least significant difference where appropriate. Shoot height and dry weight values were regressed against shoot tissue $\mathrm{P}$ concentration using SAS's PROC GLM to obtain the best-fit linear vs. quadratic model for each species. Terms of the model to include were determined using $\alpha=0.05$.

\section{Results and Discussion}

Formulated fertilizer series. In Expt. 1, results from the ANOVA indicated that tomato height was affected only by main treatment effects of phosphate-P fertilization and $\mathrm{N}$ form. Tomato shoot dry weight as well as height and dry weight of gomphrena were significantly affected by phosphate-P fertilization, $\mathrm{N}$ form, and their interaction.

When $\mathrm{N}$ was supplied in Expt.1 with either $60 \%$ or $100 \%$ in the $\mathrm{NO}_{3}{ }^{-}$form to tomato, and $100 \%$ in the $\mathrm{NO}_{3}{ }^{-}$form to gomphrena, height increased with each increase in treatment phosphate level (Fig. 1A). With $60 \%$ of $\mathrm{N}$ in the $\mathrm{NO}_{3}{ }^{-}$form, gomphrena height increased with increased phosphate-P up to $6.6 \%$ of the total $\mathrm{N}$ level and remained at that level with $21.8 \%$. Height of tomato and gomphrena was either equal or greater in treatments that supplied $\mathrm{N}$ as $100 \% \mathrm{NO}_{3}{ }^{-}$compared with $60 \% \mathrm{NO}_{3}{ }^{-}$. In Figure 1B, phosphate-P was supplied at $21.8 \%$ of the $\mathrm{N}$ level, whereas the percentage of $\mathrm{N}$ in the $\mathrm{NO}_{3}^{-}$form increased from $60 \%$ to $100 \%$. As the $\mathrm{NO}_{3}{ }^{-}$proportion increased, height increased in tomato and gomphrena. However, the effect of increasing the proportion of $\mathrm{NO}_{3}{ }^{-}$on height was much smaller than the effect of raising phosphate.

A large increase in shoot dry weight of tomato and gomphrena occurred when phosphate-P was supplied at a rate equal to $3.3 \%$
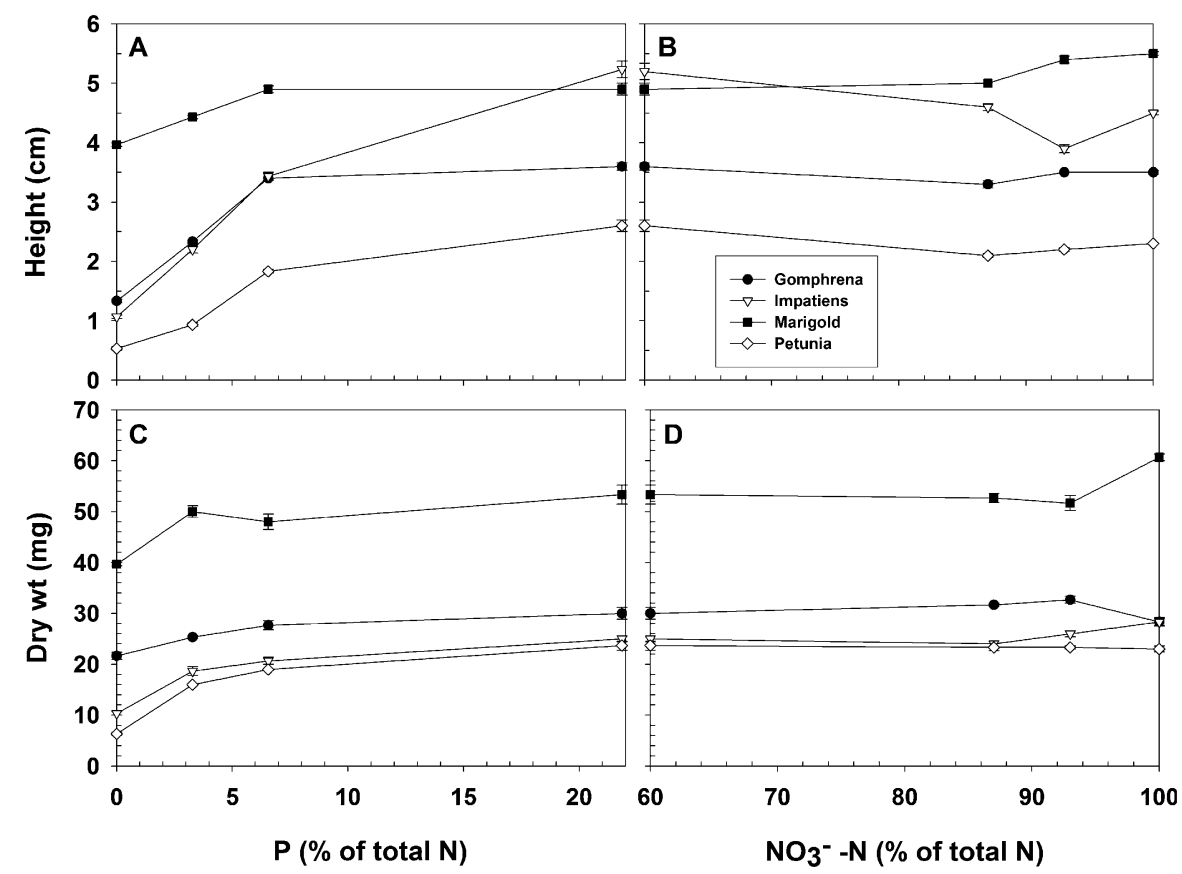

Fig. 2. Effect of fertilizer (A) phosphorus (P) levels expressed as a percentage of total nitrogen (N) and (B) $\mathrm{NO}_{4}{ }^{-}$proportions of total $\mathrm{N}$ on the height; also (C) $\mathrm{P}$ levels expressed as a percentage of total $\mathrm{N}$ and (D) $\mathrm{NO}_{4}^{-}$proportions of total $\mathrm{N}$ on the dry weight of seedling shoots of gomphrena, impatiens, marigold, and petunia at the end of plug Stage 3 in Expt. 2. Vertical bars represent SE $(\mathrm{n}=3)$.

Table 2. Effects of commercial fertilizers, varying in percentage of total $\mathrm{N}$ in the $\mathrm{NO}_{3}{ }^{-}$form and phosphate level, on height and dry weight of seedling shoots of gomphrena and tomato at the end of plug Stage 3 in Expt. 1.

\begin{tabular}{lccccccc}
\hline \multirow{2}{*}{$\begin{array}{l}\text { Treatment } \\
\text { no. }\end{array}$} & $\mathrm{N}-\mathrm{P}-\mathrm{K}^{\mathrm{z}}$ & $\mathrm{NO}_{3}{ }^{-}(\% \mathrm{~N})^{\mathrm{y}}$ & $\mathrm{P}(\% \mathrm{~N})$ & $\mathrm{Ht}(\mathrm{cm})$ & Dry wt $(\mathrm{mg})$ & & \multicolumn{2}{c}{ Homato } \\
\hline 11 & $17-0-14.1$ & 80 & 0 & $\mathrm{~cm})$ & Dry wt $(\mathrm{mg})$ \\
12 & $15-0-12.5$ & 87 & 0 & 2.9 & 39 & 13.4 & 62 \\
13 & $14-0-11.6$ & 92 & 0 & 3.6 & 44 & 13.7 & 65 \\
14 & $13-0.9-10.8$ & 95 & 6.6 & 4.8 & 54 & 16.9 & 73 \\
15 & $15-3.3-12.5^{\mathrm{x}}$ & 87 & 21.8 & 4.5 & 54 & 15.9 & 66 \\
4 & $20-4.4-16.6^{\mathrm{w}}$ & 60 & 21.8 & 4.1 & 43 & 16.3 & 65 \\
& & & & 0.2 & 3 & 0.3 & 2 \\
\hline
\end{tabular}

${ }^{\mathrm{z}}$ All treatments were applied at $100 \mathrm{mg} \cdot \mathrm{L}^{-1} \mathrm{~N}$ and $83 \mathrm{mg} \cdot \mathrm{L}^{-1} \mathrm{~K}$.

${ }^{y}$ Nitrate and $\mathrm{P}$ levels in the fertilizer solutions were expressed as a percentage of the total $\mathrm{N}$ in the solution. ${ }^{x}$ The 15-3.3-12.5 treatment was the 15-0-12.5 commercial fertilizer amended with $\mathrm{Ca}\left(\mathrm{H}_{2} \mathrm{PO}_{4}\right)_{2}$ to provide phosphate while maintaining the $\mathrm{N}$ to $\mathrm{K}$ ratio.

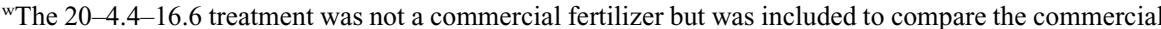
fertilizers with high $\mathrm{NO}_{3}{ }^{-}$levels $(80 \%$ to $92 \%$ of total $\mathrm{N})$ to a fertilizer with relatively low $\mathrm{NO}_{3}{ }^{-}$levels $(60 \%$ of total $\mathrm{N})$.

$\mathrm{N}=$ nitrogen; $\mathrm{P}=$ phosphorus; $\mathrm{K}=$ potassium; $\mathrm{LSD}=$ least significant difference . 
of the $\mathrm{N}$ level compared with zero phosphate$\mathrm{P}$ in both the $60 \%$ and $100 \% \mathrm{NO}_{3}^{-}$series (Fig. 1C). Further increases of phosphate did not result in taller plants. At all phosphate levels, the increase from $60 \%$ to $100 \%$ of $\mathrm{N}$ in the $\mathrm{NO}_{3}{ }^{-}$form resulted in increased dry weight. In the treatments in which $\mathrm{NO}_{3}{ }^{-}$form of $\mathrm{N}$ was increased from $60 \%$ to $100 \%$ of $\mathrm{N}$, whereas phosphate-P was held constant at $21.8 \%$ of $\mathrm{N}$ (Fig. 1D), dry weight of tomato and gomphrena increased with increasing proportion of $\mathrm{NO}_{3}{ }^{-}$.

In the Expt. 2 phosphate series at low $\mathrm{NO}_{3}{ }^{-}$ (Fig. 2A), height increased in gomphrena, impatiens, and petunia with each increase in phosphate and increased in marigold with each phosphate-P increase up to $6.6 \%$ phosphate-P above which it remained constant. In the $\mathrm{NO}_{3}{ }^{-}$ series at high phosphate-P (Fig. 2B), increased $\mathrm{NO}_{3}^{-}$proportion resulted in increased height in marigold, had little effect in gomphrena and petunia, and showed a decrease in impatiens. Again, the phosphate effect was much greater than the $\mathrm{NO}_{3}{ }^{-}$effect.

Dry weight response in Expt. 2 largely followed height in the phosphate series at low $\mathrm{NO}_{3}{ }^{-}$(Fig. 2C), increasing in all four species with increasing phosphate. When phosphate-P was held constant at $21.8 \%$ of the fertilizer $\mathrm{N}$ level and the proportion of $\mathrm{N}$ in the $\mathrm{NO}_{3}{ }^{-}$form was increased from $60 \%$ to $100 \%$ (Fig. 2D), there was a small increase in dry weight in marigold and impatiens and no net effect in gomphrena and petunia. Like in the first experiment, the effect of $\mathrm{NO}_{3}{ }^{-}$proportion on height and dry weight was very small compared with the effect of phosphate level.

Commercial fertilizer series. Within the commercial series of fertilizers in Expt. 1 (Table 2), Treatments 11, 12, and 13 contained no phosphate-P; however, the proportion of $\mathrm{N}$ in the $\mathrm{NO}_{3}{ }^{-}$form increased in the order of the treatment number. Height and dry weight of tomato and gomphrena increased with increasing proportion of $\mathrm{NO}_{3}{ }^{-}$. Phosphate was supplied in Treatments 14 and 15 and these resulted in large increases in height and dry weight in both species compared with the treatments without phosphate.

When phosphate was added to Treatment 12 in Expts. 1 and 2 (Tables 2 and 3, respectively) to raise the phosphate-P level from zero to $21.8 \%$ of the $\mathrm{N}$ level (Treatment 15 ), large increases in height and dry weight occurred in all five species tested. In both experiments, the larger heights and dry weights resulting from phosphate addition in Treatment 15 were closer to those in Treatment 4 (a $20 \mathrm{~N}-10 \mathrm{P}_{2} \mathrm{O}_{5}-20 \mathrm{~K}_{2} \mathrm{O}$ fertilizer with $60 \%$ of $\mathrm{N}$ in the $\mathrm{NO}_{3}{ }^{-}$form and phosphate-P at $21.8 \%$ of $\mathrm{N}$ ) than to those in Treatment 12 (without phosphate-P). This further indicated that height and dry weight suppression in Treatment 12 was controlled by low phosphate rather than high $\mathrm{NO}_{3}{ }^{-}$proportion.

Correlation of tissue phosphorus level with growth. Expts. 1 and 2 shoot heights (Figs. 3A and $3 \mathrm{C}$, respectively) and dry weights (Figs. $3 \mathrm{~B}$ and $3 \mathrm{D}$, respectively) for all treatments within each experiment were plotted against

Table 3. Effects of commercial fertilizers, varying in percentage of total $\mathrm{N}$ in the $\mathrm{NO}_{3}{ }^{-}$form and phosphate level, on height and dry weight of seedling shoots of gomphrena, impatiens, marigold, and petunia at the end of plug Stage 3 in Expt. 2.

\begin{tabular}{|c|c|c|c|c|c|c|c|c|c|c|c|}
\hline \multirow[b]{2}{*}{$\begin{array}{l}\text { Treatment } \\
\text { no. }\end{array}$} & \multirow[b]{2}{*}{$\mathrm{N}-\mathrm{P}-\mathrm{K}^{\mathrm{z}}$} & \multirow[b]{2}{*}{$\begin{array}{l}\mathrm{NO}_{3}{ }^{-} \\
(\% \mathrm{~N})^{\mathrm{y}}\end{array}$} & \multirow[b]{2}{*}{$\begin{array}{c}\mathrm{P} \\
(\% \mathrm{~N})\end{array}$} & \multicolumn{2}{|c|}{ Gomphrena } & \multicolumn{2}{|c|}{ Impatiens } & \multicolumn{2}{|c|}{ Marigold } & \multicolumn{2}{|c|}{ Petunia } \\
\hline & & & & $\begin{array}{l}\mathrm{Ht} \\
(\mathrm{cm})\end{array}$ & $\begin{array}{c}\text { Dry wt } \\
\text { (mg) }\end{array}$ & $\begin{array}{c}\mathrm{Ht} \\
(\mathrm{cm})\end{array}$ & $\begin{array}{c}\text { Dry wt } \\
(\mathrm{mg})\end{array}$ & $\begin{array}{c}\mathrm{Ht} \\
(\mathrm{cm})\end{array}$ & $\begin{array}{c}\text { Dry wt } \\
\text { (mg) }\end{array}$ & $\begin{array}{l}\mathrm{Ht} \\
(\mathrm{cm})\end{array}$ & $\begin{array}{c}\text { Dry wt } \\
(\mathrm{mg})\end{array}$ \\
\hline 12 & $15-0-12.5$ & 87 & 0 & 1.3 & 23 & 1.0 & 13 & 3.8 & 44 & 0.5 & 7 \\
\hline 15 & $15-3.3-12.5^{\mathrm{x}}$ & 87 & 21.8 & 3.3 & 31 & 4.3 & 29 & 5.4 & 62 & 2.2 & 24 \\
\hline 4 & $20-4.4-16.6^{\mathrm{w}}$ & 60 & 21.8 & 3.6 & 30 & 5.2 & 25 & 4.9 & 53 & 2.6 & 24 \\
\hline & \multicolumn{3}{|c|}{$\operatorname{LSD}_{0.05}$} & 0.1 & 3 & 0.4 & 2 & 0.3 & 7 & 0.3 & 2 \\
\hline
\end{tabular}

${ }^{\mathrm{z}}$ All treatments were applied at $100 \mathrm{mg} \cdot \mathrm{L}^{-1} \mathrm{~N}$ and $83 \mathrm{mg} \cdot \mathrm{L}^{-1} \mathrm{~K}$.

${ }^{\mathrm{y}}$ Nitrate and $\mathrm{P}$ levels in the fertilizer solutions were expressed as a percentage of the total $\mathrm{N}$ in the solution. ${ }^{x}$ The 15-3.3-12.5 treatment was the 15-0-12.5 commercial fertilizer amended with $\mathrm{Ca}\left(\mathrm{H}_{2} \mathrm{PO}_{4}\right)_{2}$ to provide phosphate while maintaining the $\mathrm{N}$ to $\mathrm{K}$ ratio.

${ }^{\text {w}}$ The 20-4.4-16.6 treatment was not a commercial fertilizer but was included to compare the commercial fertilizers with high $\mathrm{NO}_{3}{ }^{-}$levels $(87 \%$ of total $\mathrm{N})$ to a fertilizer with relatively low $\mathrm{NO}_{3}{ }^{-}$levels $(60 \%$ of total $\mathrm{N})$.

$\mathrm{N}=$ nitrogen; $\mathrm{P}=$ phosphorus; $\mathrm{K}=$ potassium; $\mathrm{LSD}=$ least significant difference.
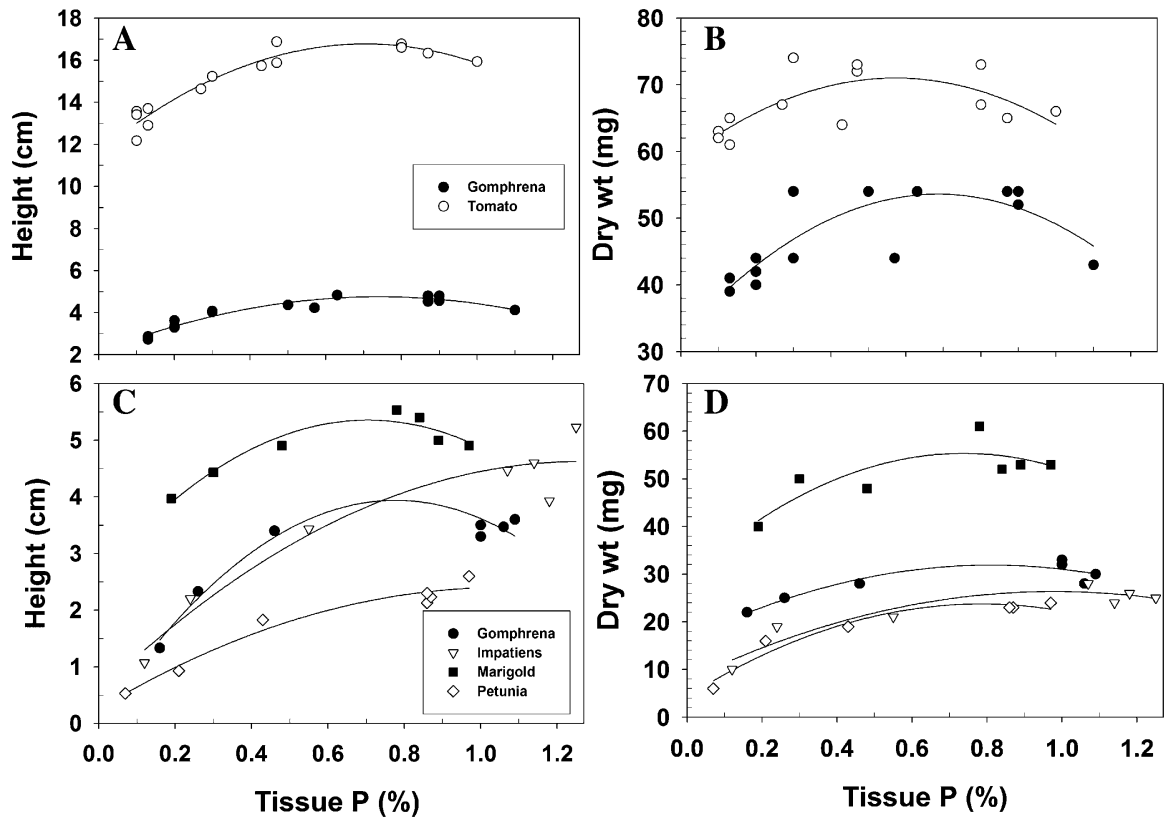

Fig. 3. Effect of shoot tissue phosphorus $(\mathrm{P})$ concentration on the $(\mathbf{A})$ height and $(\mathbf{B})$ dry weight of seedling shoots of tomato and gomphrena in Expt. 1 and (C) height and (D) dry weight of seedling shoots of gomphrena, impatiens, marigold, and petunia in Expt. 2 at the end of plug Stage 3. Regression lines were generated for the best fit model $(\mathrm{n}=3)$. The regression equations for the graphs were $(\mathbf{A})$ $\mathrm{y}_{\text {gomphrena ht }}=-4.34 \mathrm{x}^{2}+6.53 \mathrm{x}+2.28\left(r^{2}=0.89\right), \mathrm{y}_{\text {tomato } \mathrm{ht}}=-9.61 \mathrm{x}^{2}+14.2 \mathrm{x}+11.6\left(r^{2}=0.90\right) ;(\mathbf{B})$ $\mathrm{y}_{\text {gomphrena dry wt }}=-42.7 \mathrm{x}^{2}+58.5 \mathrm{x}+33.4\left(r^{2}=0.65\right), \mathrm{y}_{\text {tomato dry wt }}=-31.3 \mathrm{x}^{2}+37.9 \mathrm{x}+59.3\left(r^{2}=0.44\right)$; (C) $\mathrm{y}_{\text {gomphrena ht }}=-5.82 \mathrm{x}^{2}+9.24 \mathrm{x}+0.127\left(r^{2}=0.92\right), \mathrm{y}_{\text {impatiens ht }}=-2.72 \mathrm{x}^{2}+6.71 \mathrm{x}+0.434\left(r^{2}=0.94\right)$, $\mathrm{y}_{\text {marigold ht }}=-4.77 \mathrm{x}^{2}+6.85 \mathrm{x}+2.87\left(r^{2}=0.92\right), \mathrm{y}_{\text {petunia ht }}=-1.50 \mathrm{x}^{2}+3.58 \mathrm{x}+0.329\left(r^{2}=0.96\right)$; and (D) $\mathrm{y}_{\text {gomphrena dry wt }}=-20.5 \mathrm{x}^{2}+34.2 \mathrm{x}+17.3\left(r^{2}=0.86\right), \mathrm{y}_{\text {impatiens dry } w t}=-20.4 \mathrm{x}^{2}+39.5 \mathrm{x}+7.75\left(r^{2}=0.90\right)$, $\mathrm{y}_{\text {marigold dry wt }}=-39.8 \mathrm{x}^{2}+59.9 \mathrm{x}+33.5\left(r^{2}=0.62\right), \mathrm{y}_{\text {petunia dry } w t}=-28.8 \mathrm{x}^{2}+46.8 \mathrm{x}+4.81\left(r^{2}=0.95\right)$.

their associated shoot tissue $\mathrm{P}$ concentrations. Both variables were found to increase with increasing tissue $\mathrm{P}$ concentrations greatly above the minimum critical tissue $P$ levels of $0.25 \%$ to $0.30 \%$ of dry weight reported for general floral crops during mid- to late stages of production (Dole and Wilkins, 2004; Mills and Jones, 1996). Tomato height and dry weight were maximum in Expt. 1 at tissue $P$ concentrations of $\approx 0.7 \%$ and $0.6 \%$, respectively. Height and dry weight of gomphrena were maximized at approximate tissue $\mathrm{P}$ concentrations between $0.7 \%$ and $0.8 \%$ in Expt. 1 and $0.8 \%$ and $0.9 \%$ in Expt. 2. In Expt. 2, maximum height and dry weights of marigold, petunia, and impatiens occurred in the tissue $P$ ranges of $0.7 \%$ to $0.8 \%, 0.8 \%$ to $1.1 \%$, and $1.0 \%$ to $1.3 \%$, respectively. Clearly, the minimum critical tissue $\mathrm{P}$ concentrations for these young bedding plants, based on maximum growth, are in the range of $0.6 \%$ to $1.3 \%$ and sometimes higher.

Typically, a broad luxury consumption plateau exists for $\mathrm{P}$ tissue concentrations above the minimum critical level. In this plateau, growth does not change with rising tissue $P$ concentrations. If a luxury consumption plateau exists for tissue $\mathrm{P}$ concentrations in these young bedding plants, it is above $0.6 \%$ to $1.3 \%$. Thus, tissue $\mathrm{P}$ concentrations that do not promote increased growth for many other floral crops with a low minimum critical level will 
stimulate increased growth for young plants. This relationship of tissue $\mathrm{P}$ to growth is very important for commercial growers of plug seedlings and bedding plants because they need to produce compact plants. This can be accomplished by maintaining tissue $\mathrm{P}$ concentrations that are below the minimum critical levels and in the zone of moderate $\mathrm{P}$ deficiency.

\section{Conclusions}

These data support the commonly held industry concept that shoot height can be suppressed by applying high $\mathrm{NO}_{3}^{-}$fertilizers. At the same time, they refute the industry explanation for this phenomenon, i.e., that it is the proportion of $\mathrm{NO}_{3}{ }^{-}$to $\mathrm{NH}_{4}{ }^{+}$that controls height. High $\mathrm{NO}_{3}^{-}$fertilizers are either devoid or low in phosphate. This study demonstrated that the low phosphate level in these fertilizers strongly induced compactness, whereas the higher proportions of $\mathrm{N}$ in the $\mathrm{NO}_{3}{ }^{-}$form had a comparatively weak effect on compactness. In most cases in this study, increased proportion of $\mathrm{NO}_{3}{ }^{-}$caused the reverse effect, i.e., increased plant size.

\section{Literature Cited}

Argo, W.R. and J.A. Biernbaum. 1997. Lime, water source, and fertilizer nitrogen form affect medium $\mathrm{pH}$ and nitrogen accumulation and uptake. HortScience 32:71-74.

Berghage, R.D. and R.D. Heins. 1991. Quantification of temperature effects on stem elongation in poinsettia. J. Amer. Soc. Hort. Sci. 116:14-18.
Cataldo, D.A., M. Haroon, L.E. Schrader, and V.L. Youngs. 1975. Rapid colorimetric determination of nitrate in plant tissue. Commun. Soil Sci. Plant Anal. 6:71-80.

Chaney, A.L. and E.P. Marbach. 1962. Modified reagents for determination of urea and ammonium. Clin. Chem. 8:130-132.

Chapman, H.D. and P.F. Pratt. 1961. Methods of analysis for soils, plants, and waters. Univ. Calif., Div. Agr. Sci., Berkley, CA.

Cox, W.J. and H.M. Reisenauer. 1973. Growth and ion uptake by wheat supplied nitrogen as nitrate, or ammonium, or both. Plant Soil 38:363-380.

Dole, J.M. and H.F. Wilkins. 2004. Floriculture principles and species. Pearson Prentice Hall, Upper Saddle River, NJ.

Fleck, A. and J. Davidson. 1974. Micro determination of nitrogen. Crit. Rev. Anal. Chem. 4:141-154.

Gaffney, J.M., R.S. Lindstrom, A.R. McDaniel, and A.J. Lewis. 1982. Effect of ammonium and nitrate nitrogen on growth of poinsettia. HortScience 17:603-604.

Gaston, M.L., P.S. Konjoian, L.A. Kunkle, and M.F. Wilt (eds.). 2001. Tips on regulating growth of floriculture crops. O.F.A. Services, Columbus, $\mathrm{OH}$.

Gibson, J.L., D.S. Pitchay, A.L. Williams-Rhodes, B.E. Whipker, P.V. Nelson, and J.M. Dole. 2007. Nutrient deficiencies in bedding plants. Ball Publishing, Batavia, IL.

Goldstein, A., D. Baertlein, and R. McDaniel. 1988. Phosphate starvation inducible metabolism in Lycopersicon esculentum. I. Excretion of acid phosphate by tomato plants and suspensioncultured cells. Plant Physiol. 87:711-715.

Green, J.L., W.D. Holley, and B. Thaden. 1973. Effects of the $\mathrm{NH}_{4}{ }^{+}: \mathrm{NO}_{3}{ }^{-}$ratio, chloride, Nserve, and simazine on carnation flower production and plant growth. Proc. Fla. State Hort. Soc. 86:383-388.
Haynes, R.J. and K.M. Goh. 1978. Ammonium and nitrate nutrition of plants. Biol. Rev. Camb. Philos. Soc. 53:465-510.

Huang, J. and P.V. Nelson. 1994. Phosphorus supply control of bedding plant seedling root/shoot ratio. HortScience 29:502 (abstr.)

Jeong, B.R. and C.W. Lee. 1992. Ammonium and nitrate nutrition of 11 bedding plant species. Acta Hort. 319:505-510.

Loneragan, J. and C. Asher. 1967. Response of plants to phosphate concentration in solution culture: II. Rates of phosphate absorption and its relation to growth. Soil Sci. 103:311-318.

Mills, H.A. and J.B. Jones. 1996. Plant analysis handbook II. Micro Macro Publishing, Athens, GA.

Murphy, J. and J.P. Riley. 1962. A modified single solution for the determination of phosphate in natural waters. Anal. Chim. Acta 27: 331-336.

Schnelle, M.A., B.D. McCraw and J.M. Dole. 1993. Height control for flowering and vegetable transplants. Oklahoma State Univ. Extension Facts No. 7614.

Schrock, P.T. and K.L. Goldsberry. 1982. Growth responses of seed geranium and petunia to $\mathrm{N}$ sources and growing media. J. Amer. Soc. Hort. Sci. 107:348-352.

Styer, R.C. and D.S. Koranski. 1997. Plug and transplant production: A grower's guide. Ball Publishing, Batavia. IL.

Tayama, H.K., R.A. Larson, P.A. Hammer, and T.J. Roll (eds.). 1992. Tips on the use of chemical growth regulators on floriculture crops. Ohio Florists' Assoc., Columbus, $\mathrm{OH}$.

Trull, M.C., M.J. Guiltinan, J.P. Lynch, and J. Deikman. 1997. The responses of wild-type and ABA mutant Arabidopsis thaliana plants to phosphorus starvation. Plant Cell Environ. 20:65-92. 